\title{
Heterotrophic Nitrification in Thiosphaera pantotropha: Oxygen Uptake and Enzyme Studies
}

\author{
By LESLEY A. ROBERTSON* AND J. GIJS KUENEN \\ Laboratory of Microbiology and Enzymology, Delft University of Technology, Julianalaan 67A, \\ 2628 BC Delft, The Netherlands
}

(Received 22 July 1987; revised 7 December 1987)

\begin{abstract}
Thiosphaera pantotropha is a heterotrophic nitrifying bacterium which reduces nitrite produced from ammonia to nitrogen gas, regardless of the ambient dissolved $\mathrm{O}_{2}$ concentration. Under certain growth conditions, nitrous oxide may be produced. The ammonia oxygenase showed a number of similarities with that of autotrophic nitrifiers [e.g. light sensitivity, $\mathrm{Mg}^{2+}$ requirement, $\mathrm{NAD}(\mathrm{P}) \mathrm{H}$ utilization], as did the hydroxylamine oxidoreductase (cytochrome $c$ oxidation, hydrazine inhibition). However, there were also differences (e.g. hydroxylamine inhibition of ammonia oxidation) and this apparent similarity may be superficial. Control experiments with a strain of Paracoccus denitrificans (which does not nitrify) did not show the presence of either enzyme.
\end{abstract}

\section{INTRODUCTION}

Heterotrophic nitrification is still a poorly understood microbiological process. Killham (1986) has shown that in fungi the oxidation of reduced nitrogen compounds proceeds, at least in part, via organic compounds. However, Verstraete (1975) reported that in some heterotrophic bacteria, the oxidation of ammonia and related compounds to nitrite is a bypass of a pathway for the synthesis of chelating agents when iron is limiting. Many denitrifying bacteria also nitrify heterotrophically (Castignetti \& Hollocher, 1984). Thiosphaera pantotropha is a heterotrophic nitrifying bacterium which co-respires nitrate and oxygen according to the scheme shown in Fig. 1 (Robertson \& Kuenen, 1983, 1984a, b). Implicit in this scheme is the concept that this bacterium actively converts ammonia to nitrogen gas under aerobic conditions without the accumulation of intermediates such as hydroxylamine or nitrite. Thus, in contrast to other heterotrophic nitrifiers, organisms of this type cannot be recognized by nitrite accumulation in the culture medium. Current studies in this laboratory have demonstrated that heterotrophic nitrification and 'aerobic denitrification' (co-respiration of nitrate or nitrite and oxygen) are not restricted to $T$. pantotropha, but occur also in a hitherto unrecognized group of heterotrophic nitrifiers which do not accumulate nitrite. To appreciate the importance of these bacteria in the natural environment and waste-water treatment systems, it is essential to understand the mechanisms by which the two processes occur. This paper describes experiments performed to reveal the nature of the enzymes and pathway involved in heterotrophic nitrification in $T$. pantotropha. Paracoccus denitrificans was included for comparison as it does not nitrify and only denitrifies under anaerobic conditions (Alefounder et al., 1985; L. A. Robertson, E. W. J. van Niel, R. Torremans \& J. G. Kuenen, unpublished results).

\section{METHODS}

Organisms and growth. Thiosphaera pantotropha LMD 82.5 was originally isolated from a denitrifying, sulphideoxidizing waste-water treatment system (Robertson \& Kuenen, 1983). Paracoccus denitrificans LMD 22.21 was obtained from the Delft Culture Collection, and is the strain isolated by Beijerinck (1910). 


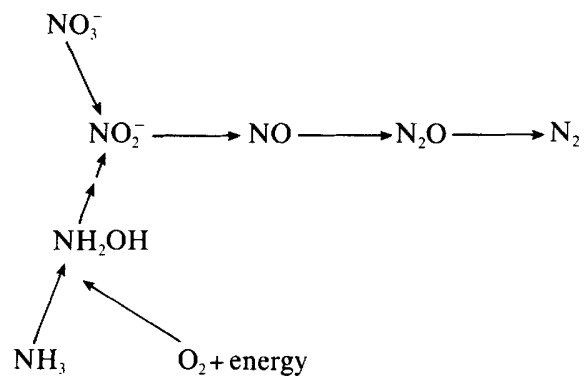

Fig. 1. Schematic representation of the interlinking pathways of heterotrophic nitrification and denitrification as they probably occur in $T$. pantotropha.

The batch culture medium (Robertson \& Kuenen, 1983) contained ( $\left.\mathrm{g} \mathrm{l}^{-1}\right): \mathrm{Na}_{2} \mathrm{HPO}_{4} .7 \mathrm{H}_{2} \mathrm{O}, 7 \cdot 9 ; \mathrm{KH}_{2} \mathrm{PO}_{4}, 1 \cdot 5$; $\mathrm{NH}_{4} \mathrm{Cl}, 0 \cdot 3 ; \mathrm{MgSO}_{4} .7 \mathrm{H}_{2} \mathrm{O}, 0 \cdot 1$; and $2 \mathrm{ml}$ trace element solution $\mathrm{l}^{-1}$ (Vishniac \& Santer, 1957). The medium supplied to the chemostat contained $\left(\mathrm{gl}^{-1}\right): \mathrm{K}_{2} \mathrm{HPO}_{4}, 0.8 ; \mathrm{KH}_{2} \mathrm{PO}_{4}, 0.3 ; \mathrm{NH}_{4} \mathrm{Cl}, 0.4 ; \mathrm{MgSO}_{4} .7 \mathrm{H}_{2} \mathrm{O}, 0.4 ;$ and $2 \mathrm{ml}$ trace element solution. Acetate (sodium salt; $10 \mathrm{mM}$ and $20 \mathrm{mM}$ ) was supplied as substrate to batch and chemostat cultures, respectively.

Mixotrophic cultures were grown in the chemostat with $20 \mathrm{~mm}$-acetate and $5 \mathrm{~mm}$-sodium thiosulphate. $\mathrm{KNO}_{3}$ (40 mM) was added in some experiments. Batch cultures were grown in Kluyver flasks (culture vol., 11 ; headspace, 11) (Robertson \& Kuenen, 1984b) which incorporated an oxygen electrode. When needed, cells were grown anaerobically by sparging either with $\mathrm{Ar}$ or with $\mathrm{O}_{2}$-free nitrogen. $T$. pantotropha was grown at $37^{\circ} \mathrm{C}$ and $P$. denitrificans at $30^{\circ} \mathrm{C}$. Continuous cultures were grown in chemostats (culture vol., 1.51; headspace, 11 ) fitted with dissolved $\mathrm{O}_{2}$ and $\mathrm{pH}$ control. The temperature was maintained at 30 or $37^{\circ} \mathrm{C}$, the dissolved oxygen at $80 \%$ air saturation and the $\mathrm{pH}$ at 8.0 . The dilution rates ranged between 0.04 and $0.06 \mathrm{~h}^{-1}$.

Preparation of cell extracts. Biomass for the preparation of extracts was harvested from the chemostats by centrifugation $(40000 \mathrm{~g}, 20 \mathrm{~min})$, washed twice in $0.05 \mathrm{M}$-phosphate buffer $(\mathrm{pH} 8.0)$ and frozen as pellets at $-20{ }^{\circ} \mathrm{C}$. Immediately before use, the cells were disrupted ultrasonically in the presence of $50 \%(\mathrm{w} / \mathrm{v}) \mathrm{Ballotini}$ beads (diameter $0.11 \mathrm{~mm}$ ) and then centrifuged $(10000 \mathrm{~g}, 5 \mathrm{~min})$ to remove remaining whole cells and debris. During and after disruption, the extracts were kept at $0-4{ }^{\circ} \mathrm{C}$ in the dark.

Buffers. The HEPES buffer used during experiments with the extracts contained $100 \mathrm{mM}-\mathrm{HEPES}, 15 \mathrm{mM}-$ $\mathrm{MgCl}_{2}$ and $4 \mathrm{~mm}$-EDTA. The pH was adjusted to 7.0 with $\mathrm{KOH}$. A $0.05 \mathrm{M}$-potassium phosphate buffer, pH 8.0 , was used as specified.

$\mathrm{O}_{2}$ uptake experiments. $\mathrm{O}_{2}$ uptake was measured using a Clark-type electrode mounted in a thermostatically controlled cell which was closed except for a small hole through which additions could be made. Nitrous oxide was detected by the oxygen electrode under anaerobic conditions created by the addition of baker's yeast (Kucera et al., 1984). The effect of thiosulphate on $\mathrm{O}_{2}$ uptake was determined in heterotrophically grown cultures which were not induced for thiosulphate oxidation. In all cases, the accuracy of the results was better than $\pm 5 \%$.

Chemical analyses. Protein was measured by the micro-biuret method (Goa, 1953). Nitrate was measured with the Griess-Romijn reagent (Griess-Romijn van Eck, 1966). Ammonia was determined by following the oxidation of NADH in the presence of 2-oxoglutarate and L-glutamate dehydrogenase using a test kit (Sigma). Since both ammonia and ammonium would be present at the $\mathrm{pH}$ values used, the term ammonia will be used to cover both the protonated and unprotonated forms. Hydroxylamine was determined as described by Frear \& Burrell (1955).

\section{RESULTS AND DISCUSSION}

\section{Ammonia disappearance}

Nitrogen balances for aerobic chemostat cultures showed that ammonia was being lost. Since control experiments in an uninoculated chemostat indicated that the maximum ammonia loss due to sparging was less than $0.006 \mu \mathrm{mol}^{-1} \mathrm{~h}^{-1}$ this disappearance was assumed to be a consequence of nitrification/denitrification. Up to $71 \mu \mathrm{mol}$ ammonia $\mathrm{l}^{-1} \mathrm{~h}^{-1}$ was lost from cultures grown with acetate and ammonia. In the presence of nitrate ( $20 \mathrm{~mm}$ in the influent), nitrite (10 or $20 \mathrm{~mm})$, thiosulphate $(5 \mathrm{~mm})$, thiosulphate and nitrate ( 5 and $20 \mathrm{~mm}$, respectively) and hydroxylamine (1-4 mM), 25, 65, 41, 16 and $33 \mu \mathrm{mol}$ ammonia $\mathrm{l}^{-1} \mathrm{~h}^{-1}$, respectively, was nitrified and subsequently denitrified. These losses represent in vivo specific activities ranging from $5-43 \mathrm{nmol}$ ammonia oxidized $\mathrm{min}^{-1}$ (mg protein) $)^{-1}$. 
Table 1. Effect of $\mathrm{pH}$ on ammonia-dependent $\mathrm{O}_{2}$ uptake by cell-free extracts of $T$. pantotropha

Extracts in HEPES buffer were incubated with $5 \mathrm{mM}-\mathrm{Mg}^{2+}$ and $0.63 \mathrm{~mm}-\mathrm{NADPH}$. The cells had been grown in an acetate-limited chemostat at a dissolved $\mathrm{O}_{2}$ level of $40 \%$ air saturation, with ammonia as the sole source of nitrogen.

\begin{tabular}{|c|c|c|}
\hline \multirow[b]{2}{*}{$\mathrm{pH}$} & \multicolumn{2}{|c|}{$\begin{array}{c}\mathrm{O}_{2} \text { uptake rate } \\
{\left[\mathrm{nmol}(\mathrm{mg} \text { protein })^{-1} \mathrm{~min}^{-1}\right]}\end{array}$} \\
\hline & $5 \mathrm{mM}-\mathrm{NH}_{4}^{+}$ & $10 \mathrm{mM}-\mathrm{NH}_{4}^{+}$ \\
\hline $8 \cdot 7$ & 1.9 & $2 \cdot 5$ \\
\hline $8 \cdot 7^{*}$ & 0 & 0 \\
\hline $9 \cdot 0$ & $2 \cdot 9$ & $3 \cdot 4$ \\
\hline $10 \cdot 5$ & 0.5 & 0.9 \\
\hline
\end{tabular}

\section{Ammonia oxygenase}

Ammonia oxidation, measured as $\mathrm{O}_{2}$ uptake, could be demonstrated in cell-free extracts of $T$. pantotropha in the presence of NADPH and $\mathrm{Mg}^{2+}$ provided that light was excluded. Trace amounts of hydroxylamine $(<3 \mu \mathrm{M})$, the expected product of this oxidation, appeared during the first few minutes of the experiment. However, the reaction stopped before the hydroxylamine concentration reached a level at which it could be accurately estimated (about $5 \mu \mathrm{M}$ ). Initially, it appeared that ammonia oxidation was optimal at $\mathrm{pH}$ values $>10$, but this was shown to be an artefact due to the masking effect of NADPH oxidase. When this was taken into account, the highest rates were recorded at $\mathrm{pH} 9.0$ (Table 1). The reaction rate increased with the

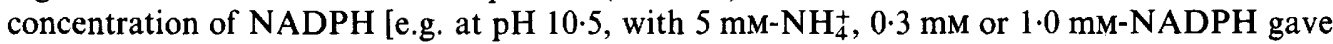
$\mathrm{O}_{2}$ uptake rates of 0.2 and $1.0 \mathrm{nmol} \mathrm{min}{ }^{-1}(\mathrm{mg} \text { protein })^{-1}$, respectively]. Doubling the amount of extract doubled the rate of $\mathrm{O}_{2}$ uptake. Boiled extract, and cell extracts which had been exposed to normal laboratory lighting for several hours, did not give a reaction and little or no activity was detected if $\mathrm{Mg}^{2+}$ was omitted. These data indicate that it was unlikely that ammonium ions were acting as an uncoupling agent of $\mathrm{NAD}(\mathrm{P}) \mathrm{H}$ respiration by membrane vesicles in the cellfree extracts. At $\mathrm{pH} 8.7$ and $\mathrm{pH} 10 \cdot 0$, NADH-dependent activity could not be detected using $5 \mathrm{mM}-\mathrm{NH}_{4}^{+}$. When $10 \mathrm{mM}-\mathrm{NH}_{4}^{+}$was used, a very low level of activity $[0.14 \mathrm{nmol} \mathrm{O}$ (mg protein $)^{-1} \mathrm{~min}^{-1}$ ] was detected. At $\mathrm{pH} 10 \cdot 5$, NADH-dependent activity was approximately $50 \%$ of the NADPH-dependent activity (with $0.63 \mathrm{~mm}-\mathrm{NADPH}$ ). We were unable to block the NADH oxidase activity (e.g. with cyanide) without also affecting the ammonia oxidation rate, except by raising the $\mathrm{pH}$. Inhibitors of $\mathrm{NADH}$ oxidase such as cyanide also inhibit the cytochrome activity of the cytochrome chain and, since nitrification is probably linked to the cytochrome chain, nitrification will also be inhibited. NADH oxidase has a $\mathrm{pH}$ optimum around $7 \cdot 0$, and becomes less active at higher $\mathrm{pH}$ values. Raising the $\mathrm{pH}$ therefore appears to be the only way to selectively inhibit the NADH oxidase without affecting nitrification. At low NADH concentrations, the NADH oxidase activity is lower and does not mask completely the effect of ammonia oxidation. Therefore it was possible to work only with NADH concentrations $(0 \cdot 31 \mathrm{~mm})$ equivalent to the lower concentrations of NADPH used.

Hooper (1981) reviewed the enzymology of ammonia oxidation by chemolithotrophic ammonia-oxidizing bacteria and reported that the ammonia oxygenase requires activation by several factors including $\mathrm{Mg}^{2+}$, and is light sensitive. The rates of ammonia oxidation recorded with cell extracts are generally insufficient to explain the in vivo rates, and this was attributed to the complexity of the enzyme system involved (Hooper, 1981). Ammonia oxidation by extracts of Nitrosomonas europaea was stimulated by NADH $\left[22 \mathrm{nmol} \mathrm{O}_{2}\right.$ consumed $\min ^{-1}$ (mg protein $)^{-1}$; the value was 0 with $\mathrm{NH}_{4}^{+}$alone], whereas whole cells of $N$. europaea oxidized 100 200 (batch-grown cells) to 260-10000 (chemostat-grown cells) $\mathrm{nmol}$ ammonia $\mathrm{min}^{-1}$ (mg protein) ${ }^{-1}$ (Suzuki et al., 1976), showing that rates recorded with cell-free extracts are at least a factor of 10 too low. The ammonia oxygenase of $T$. pantotropha is similar in some respects [e.g. light sensitivity, use of $\mathrm{NAD}(\mathrm{P}) \mathrm{H}]$ and, in addition, the $\mathrm{O}_{2}$ uptake rates in vitro were 10-20 times 


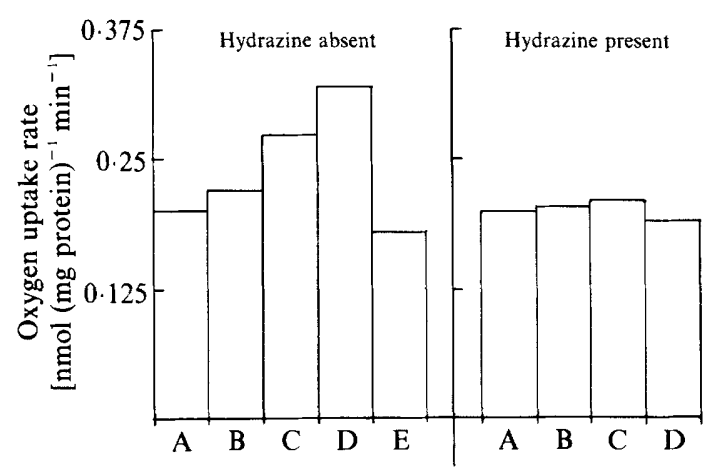

Fig. 2. Oxidation of hydroxylamine (as measured by $\mathrm{O}_{2}$ uptake) by extracts of $T$. pantotropha in HEPES buffer, in the absence and presence of $3 \mathrm{~mm}$-hydroxylamine. An experiment where hydroxylamine was added before cytochrome $c$ gave essentially similar results. A, endogenous; B, $1.5 \mu \mathrm{M}$-cytochrome $c$ added; C, $0.05 \mathrm{~mm}$-hydroxylamine added; D, a further $0.05 \mathrm{~mm}$-hydroxylamine added; E, $0.25 \mathrm{~mm}$ nitrite added.

lower than those in whole cells grown in chemostat culture (L. A. Robertson, E. W. J. van Niel, R. Torremans \& J. G. Kuenen, unpublished results). However, ammonia oxidation by $N$. europaea extracts was also stimulated by hydroxylamine $\left[27 \mathrm{nmol} \mathrm{min}^{-1}\left(\mathrm{mg}\right.\right.$ protein) ${ }^{-1}$; the value was 0 with $\mathrm{NH}_{4}^{+}$alone], and $\mathrm{Mg}^{2+}$ could replace $\mathrm{NADH}$ (Suzuki et al., 1976). The apparent inhibition of ammonia oxidation by extracts of $T$. pantotropha after a small amount of hydroxylamine had accumulated indicates that hydroxylamine is inhibitory and implies a greater sensitivity to hydroxylamine than that reported for $N$. europaea (Dua et al., 1979). When hydroxylamine was added to the reaction mixture after ammonia oxidation had started, there was an increase in the $\mathrm{O}_{2}$ uptake rate, but the rate was the same as that obtained without cell extract. This apparent stimulation must therefore be chemical in nature (see below). The inhibition of ammonia oxidation in $T$. pantotropha by hydroxylamine has been confirmed in chemostat cultures which were supplied with both ammonia and hydroxylamine (L. A. Robertson, E. W. J. van Niel, R. Torremans \& J. G. Kuenen, unpublished results). It is possible that the in vitro assay for ammonia oxygenase in $T$. pantotropha worked best at alkaline $\mathrm{pH}$ because hydroxylamine is less stable at these $\mathrm{pH}$ values (see below) and thus might be kept below the critical inhibitory concentration. An alternative hypothesis is that free $\mathrm{NH}_{3}$ is required by the enzyme and is more available in alkaline reaction mixtures, as has been reported for the autotrophs (see, e.g., Suzuki et al., 1981).

\section{Chemical oxidation of hydroxylamine}

Since hydroxylamine was apparently an intermediate of ammonia oxidation to nitrite by $T$. pantotropha, its oxidation was studied using whole cells and cell extracts. Although hydroxylamine was stable in the reaction mixture up to $\mathrm{pH} 8 \cdot 5$, at $\mathrm{pH} 10 \cdot 0$, there was a significant amount of non-biological hydroxylamine-dependent $\mathrm{O}_{2}$ uptake (7-9 nmol $\left.\mathrm{min}^{-1} \mathrm{ml}^{-1}\right)$, and nitrite was formed $\left(1-2 \mathrm{nmol} \mathrm{min}^{-1} \mathrm{ml}^{-1}\right)$. Similar results were obtained with and without boiled cell extract and with various concentrations of NADPH.

\section{Hydroxylamine oxidoreductase}

Biological hydroxylamine-dependent $\mathrm{O}_{2}$ uptake could be shown at $\mathrm{pH} 7 \cdot 0-7 \cdot 5$ with cell-free extracts in the presence of $1.5 \mu \mathrm{M}$-cytochrome $c$ (Fig. 2) provided that HEPES buffer was used. Little or no activity was found using phosphate buffer. Hydrazine (3, 6 and $12 \mathrm{~mm}$ ) inhibited hydroxylamine-dependent $\mathrm{O}_{2}$ uptake, as in N. europaea (Dua et al., 1979), although endogenous hydroxylamine-independent $\mathrm{O}_{2}$ uptake was not affected by the concentrations of hydrazine used. Nitrite was also inhibitory (Fig. 2). Whole cells oxidized hydroxylamine slowly. Hydroxylamine oxidation rates were stimulated by the redox mediator phenazine methosulphate $(0.075 \mu \mathrm{M})$. Again, it was necessary to use HEPES buffer. The low activity obtained with phosphate buffer was similar to that found with killed cells in both buffers and 


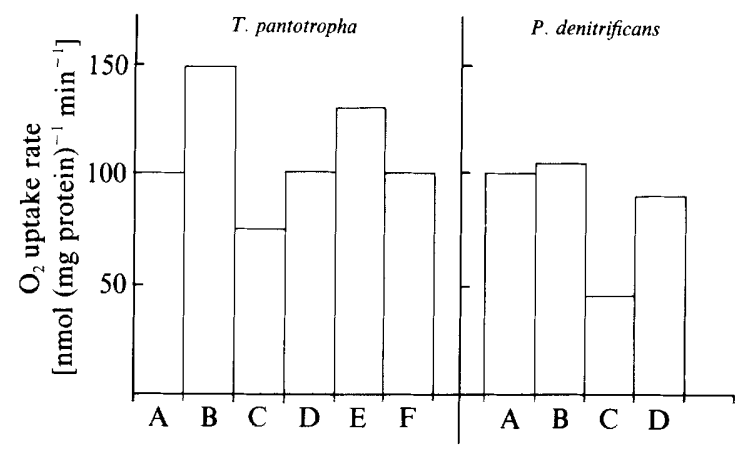

Fig. 3. Effect of $\mathrm{NH}_{4}^{+}$, hydroxylamine and nitrite on the rate of acetate-dependent $\mathrm{O}_{2}$ uptake by washed cells of $T$. pantotropha and $P$. denitrificans. The effect of thiosulphate on $T$. pantotropha is also shown. The cultures had been grown, anaerobically, to the end of the exponential phase in batch culture with acetate as the carbon and energy source and nitrate as the electron acceptor. A, control; B, $7.5 \mathrm{~mm}$ $\mathrm{NH}_{4}^{+}$; C, 1.0 mM-hydroxylamine; D, 5.0 mM-nitrite; E, $7.5 \mathrm{~mm}-\mathrm{NH}_{4}^{+}+5 \mathrm{~mm}$-thiosulphate; F, $7.5 \mathrm{~mm}$ $\mathrm{NH}_{4}^{+}+10 \mathrm{~mm}$-thiosulphate.

was presumably due to chemical oxidation reactions. Nitrite was produced from hydroxylamine by cell extracts and whole cells. Nitrous oxide production was only observed when nitrite and hydroxylamine were supplied simultaneously. A similar enzyme activity was observed in extracts of Arthrobacter globiformis, and the enzyme responsible was purified (Kurokawa et al., 1985). Activity was measured by following cytochrome $c$ reduction in Tris buffer; the optimum $\mathrm{pH}$ for hydroxylamine oxidation was $9 \cdot 0$, the reaction required iron and was inhibited by EDTA.

Using the same buffers, $\mathrm{pH}$ values and substrate concentrations, we found no evidence for the presence of either ammonia oxygenase or hydroxylamine oxidoreductase in $P$. denitrificans.

\section{$\mathrm{O}_{2}$ uptake experiments}

To characterize further the process of heterotrophic nitrification and to investigate possible influences of growth conditions, the effect of ammonia on the maximum rate of $\mathrm{O}_{2}$ uptake by $T$. pantotropha and $P$. denitrificans was compared. Both species were grown on acetate or succinate under various regimes. The cells were then harvested, washed and resuspended in phosphate buffer. Since hydroxylamine and nitrite were an intermediate and end-product, respectively, in heterotrophic nitrification by $T$. pantotropha, they were included in the respiration experiments. Similar results were obtained with acetate and succinate, and therefore only the acetate data are shown. It was anticipated that ammonia would stimulate $\mathrm{O}_{2}$ uptake by $T$.pantotropha, but not by $P$. denitrificans, and that $T$. pantotropha, as a nitrifier, should be able to oxidize hydroxylamine under aerobic conditions and thus might suffer less from its toxic effects than $P$. denitrificans. The responses of anaerobic, batch-grown cultures of $T$. pantotropha and $P$. denitrificans were indeed very different (Fig. 3). Ammonia stimulated the rate of acetate-dependent $\mathrm{O}_{2}$ uptake by $T$. pantotropha $(149 \%$ of that without ammonia), whereas $P$. denitrificans was only slightly stimulated $(5 \%)$. The presence of nitrite in the $T$. pantotropha reaction mixture was shown qualitatively. Both cultures were, to some extent, inhibited by hydroxylamine, but $P$. denitrificans was most sensitive. Nitrite alone had little effect on either culture. Ammonia stimulated the $\mathrm{O}_{2}$ uptake rate of $T$. pantotropha, but not of $P$. denitrificans (Table 2). Furthermore, all $T$. pantotropha cultures, irrespective of growth conditions, were affected by ammonia, implying that at least the ammonia oxygenase activity is constitutive. The increased stimulation of the $\mathrm{O}_{2}$ uptake rate of cells which were grown without being able to nitrify (i.e. without $\mathrm{O}_{2}$ or without ammonia, Table 2) remains, as yet, unexplained. The relative rate of $\mathrm{O}_{2}$ uptake $(110 \%)$ by cells grown in the presence of $\mathrm{O}_{2}$ and ammonia (and thus actively nitrifying during growth) increased to between 140 and $150 \%$ after $3 \mathrm{~d}$ starvation in nitrogen-free medium (although the $\mathrm{O}_{2}$ uptake rates with acetate alone were little changed), whereas starvation in the 
Table 2. Effect of ammonia and nitrite on the maximum acetate-dependent rate of $\mathrm{O}_{2}$ uptake by whole cells of $T$. pantotropha and P. denitrificans

Cells were grown aerobically or anaerobically in batch culture with acetate as carbon and energy source, and harvested at the end of the exponential phase. For ease of comparison, the results are shown as a percentage of the $\mathrm{O}_{2}$ uptake rate in phosphate buffer alone. As the experiments were done at pH 8.0, $\mathrm{NH}_{3}$ should be considered to represent a mixture of ammonia and ammonium. The values for $\mathrm{O}_{2}$ uptake [nmol (mg protein $)^{-1} \mathrm{~min}^{-1}$ ] equivalent to $100 \%$ were as follows. $T$. pantotropha aerobically grown cells, 240-250; anaerobic cells, 380. P. denitrificans: aerobic cells, 140-160; anaerobic cells, 280.

\begin{tabular}{|c|c|c|c|}
\hline \multirow[b]{2}{*}{$\begin{array}{l}\text { Growth } \\
\text { conditions }\end{array}$} & \multicolumn{3}{|c|}{ Compound added } \\
\hline & $\begin{array}{c}\mathrm{NH}_{3} \\
(10 \mathrm{mM})\end{array}$ & $\begin{array}{l}\mathrm{NH}_{2} \mathrm{OH} \\
(1 \mathrm{mM})\end{array}$ & $\begin{array}{c}\mathrm{NO}_{\overline{2}}^{-} \\
(10 \mathrm{mM})\end{array}$ \\
\hline \multicolumn{4}{|l|}{ T. pantotropha } \\
\hline $\mathrm{NH}_{3} / \mathrm{O}_{2}$ & 110 & 85 & 108 \\
\hline $\mathrm{NH}_{3} / \mathrm{NO}_{3}^{-}$ & 149 & 75 & 105 \\
\hline $\mathrm{NO}_{3}^{-} / \mathrm{O}_{2}$ & 142 & 75 & 90 \\
\hline \multicolumn{4}{|l|}{ P. denitrificans } \\
\hline $\mathrm{NH}_{3} / \mathrm{O}_{2}$ & 105 & 48 & 92 \\
\hline $\mathrm{NH}_{3} / \mathrm{NO}_{3}^{-}$ & 105 & 50 & 105 \\
\hline
\end{tabular}

Table 3. Effect of increasing hydroxylamine concentration on the rate of $\mathrm{O}_{2}$ uptake by whole cells of $T$. pantotropha

Cells were grown aerobically with nitrate or ammonium as the sole source of nitrogen. The value for $\mathrm{O}_{2}$ uptake equivalent to $100 \%$ was $240-250 \mathrm{nmol}\left(\mathrm{mg}\right.$ protein) ${ }^{-1} \mathrm{~min}^{-1}$. ND, Not determined.

\begin{tabular}{ccc}
$\begin{array}{c}\mathrm{NH}_{2} \mathrm{OH} \\
\text { concn } \\
(\mu \mathrm{M})\end{array}$ & \multicolumn{2}{c}{$\begin{array}{c}\mathrm{O}_{2} \text { uptake } \\
\text { (percentage of rate in }\end{array}$} \\
$\mathrm{NH}_{2} \mathrm{OH}$-free sample)
\end{tabular}

presence of ammonia did not affect ammonia-stimulated respiration. This might indicate that cells which had been grown and/or maintained in the presence of ammonia contained reserves of ammonia or other metabolic intermediates.

The greater sensitivity of $P$. denitrificans to hydroxylamine (Fig. 3), indicated that $T$. pantotropha, but not $P$. denitrificans, has a mechanism for detoxifying this compound. That this resistance was increased by active nitrification during the growth of the cells (implying the presence of higher concentrations of a functional hydroxylamine oxidoreductase) was also indicated by the observation that cells grown solely on ammonia $/ \mathrm{O}_{2}$ and thus nitrifying the most, were far less sensitive than those grown on nitrate (Table 3 ).

Since reduced sulphur compounds inhibit nitrification in some autotrophs (Sharma \& Ahlert, 1977; Heijnen, 1984), the effect of thiosulphate was tested on heterotrophically grown cultures of $T$. pantotropha and $P$. denitrificans. With $T$. pantotropha, ammonia had less effect on the rate of $\mathrm{O}_{2}$ uptake as the thiosulphate concentration increased (Fig. 3). Thiosulphate had no effect on $\mathrm{O}_{2}$ uptake by $T$. pantotropha or $P$. denitrificans in the absence of ammonia (results not shown). These results are in agreement with the lower amounts of ammonia nitrified in mixotrophically grown (acetate/thiosulphate) chemostat cultures (L. A. Robertson, E. W. J. van Niel, R. Torremans \& J. G. Kuenen, unpublished results). 
In conclusion, the results suggest that the enzymes of nitrification in T. pantotropha resemble those of the chemolithotrophic nitrifiers only in some respects. There is also some similarity to the NADH-dependent oxidation of ammonia and cytochrome-c-linked oxidation of hydroxylamine by extracts of Methylococcus species reported by Dalton (1977) and Drozd et al. (1978). This similarity is probably superficial. The enzyme involved in ammonia oxidation by $M$. capsulatus is methane monooxygenase, and $T$. pantotropha can neither oxidize nor grow on methane (Robertson \& Kuenen, 1983). Current studies on the cytochrome chain of $T$. pantotropha may explain why the autotrophs generate sufficient energy for growth from the reaction whereas $T$. pantotropha cannot.

The authors are grateful to Jaap Twisk and Rob Torremans for excellent experimental assistance, and to Dr Paul Wood and Ir Hans Frank for their constructive comments on the manuscript.

\section{REFERENCES}

Alefounder, P. R., Greenfield, A. J., MCCARTHY, J. E. \& Ferguson, S. J. (1985). The basis for preferential electron flow to oxygen rather than nitrogen oxides in the denitrifying bacterium Paracoccus denitrificans. In Microbial Gas Metabolism Mechanistic, Metabolic and Biotechnological Aspects, pp. 225-230. Edited by R. K. Poole \& C. S. Dow. London: Academic Press.

BEIJERINCK, W. M. (1910). Bildung und Verbrauch von Stickoxydul durch Bakterien. Zentralblatt für Bakteriologie (Abteilung II) 25, 30-63.

Castignetti, D. \& Hollocher, T. C. (1984). Heterotrophic nitrification among denitrifiers. Applied and Environmental Microbiology 47, 620-623.

Dalton, H. (1977). Ammonia oxidation by the methane oxidizing bacterium Methylococcus capsulatus strain Bath. Archives of Microbiology 114, 273279.

Drozd, J. W., Godley, A. \&.Baley, M. I. (1978). Ammonia oxidation by methane-oxidizing bacteria. Proceedings of the Society for General Microbiology 5, 66-67.

Dua, R. D., Bhandari, B. \& Nicholas, D. J. D. (1979). Stable isotope studies on the oxidation of ammonia to hydroxylamine by Nitrosomonas europaea. FEBS Letters 106, 401-404.

Frear, D. S. \& BURRELl, R. C. (1955). Spectrophotometric method for determining hydroxylamine reductase activity in higher plants. Analytical Chemistry 27, 1664-1665.

GoA, J. (1953). A microbiuret method for protein determination; determination of total protein in cerebrospinal fluid. Journal of Clinical Laboratory Investigation 5, 218-222.

GrIESS-ROMIJN VAN ECK (1966). Physiological and chemical tests for drinking water. NEN 1056, IV-2. Nederlands Normalisatie - Institut Rijswijk.

HEIJNEN, J. J. (1984). Biological industrial waste-water treatment minimizing biomass production and maximizing biomass concentration. PhD thesis, Delft University of Technology, The Netherlands.

HOOPER, A. B. (1981). Ammonia oxidation and energy transduction in the nitrifying bacteria. In Microbial
Chemoautotrophy, pp. 133-167. Edited by W. R. Strohl \& O. V. Tuovinen. Columbus: Ohio State University Press.

KILLHAM, K. (1986). Heterotrophic nitrification. In Nitrification, pp. 117-126. Edited by J. I. Prosser. Oxford: IRL Press.

KuCera, I., Boublikova, P. \& Dadak, V. (1984). Amperometric assay of activity and $\mathrm{pH}$-optimum of $\mathrm{N}_{2} \mathrm{O}$ reductase of Paracoccus denitrificans. Collection of Czechoslovak Chemical Communications. English Edition 49, 2709-2712.

Kurokawa, M., Fukumori, Y. \& Yamanaka, T. (1985). A hydroxylamine-cytochrome c reductase occurs in the heterotrophic nitrifier Arthrobacter globiformis. Plant and Cell Physiology 26, 1439-1442.

ROBERTSON, L. A. \& KUENEN, J. G. (1983). Thiosphaera pantotropha gen. nov. sp. nov., a facultatively anaerobic, facultatively autotrophic sulphur bacterium. Journal of General Microbiology 129, 28472855.

Robertson, L. A. \& Kuenen, J. G. (1984a). Aerobic denitrification: a controversy revived. Archives of Microbiology 139, 351-354.

Robertson, L. A. \& Kuenen, J. G. (1984b). Aerobic denitrification - old wine in new bottles? Antonie van Leeuwenhoek 50, 525-544.

Sharma, B. \& AhleRT, R. C. (1977). Nitrification and nitrogen removal. Water Research 11, 897-925.

SuzukI, I., KWoK, S.-C. \& DulaR, U. (1976). Competitive inhibition of ammonia oxidation in Nitrosomonas europaea by methane, carbon monoxide or methanol. FEBS Letters 72, 117-120.

Suzuki, I., KwoK, S. C., Tsang, D. C. Y., OH, J. K. \& Bhella, R. S. (1981). Oxidation of ammonia by Nitrosomonas and of inorganic sulfur by Thiobacilli. In Biology of Inorganic Nitrogen and Sulfur, pp. 212221. Edited by $H$. Bothe \& A. Trebst. Berlin: Springer.

VERSTRAETE, W. (1975). Heterotrophic nitrification in soils and aqueous media. Izvestiya Akademii nauk SSSR. Seriya biologicheskaya 4, 541-558.

VishniaC, W. \& SANTER, M. (1957). The Thiobacilli. Bacteriological Reviews 21, 195-213. 